\title{
Poética da Tensão
}

Juarez Poletto

Doutorando em Literatura (UFPR), Mestre em Literatura (UFPR), Professor de Literatura da PUCPR e do Departamento Acadêmico de Comunicação e Expressão da UTFPR, campus Curitiba. Escritor.

\section{Resumo}

Este estudo desenvolve análise de poemas do livro A rosa do povo, de Carlos Drummond de Andrade, para mostrar os vários níveis de tensão nele existentes, isto é, ampliar a visão do impasse sério/vulgar, já discutido por outros analistas, e ver como se desenvolvem as tensões temáticas, temporais, metapoéticas, formais e ideológicas.

\section{Abstract}

This study develops the analysis of poems from the book "A rosa do povo", by Carlos Drummond de Andrade, in order to show the several tension levels existing in them, so that a broaden view of the serious/vulgar stalemate, which has been discussed by other analysts, is achieved; such analysis is also meant to realize how do tensions on thematic, temporal, metapoetic, formal and ideological levels develop.

José Guilherme Merquior diferencia as obras de Carlos Drummond de Andrade Sentimento do Mundo e José, pelo sentido de ruptura que esta representa em relação àquela; não uma ruptura temática - pois considera que há aprofundamento a esse respeito - mas afiança que esta última “dá marcha à ré em relação às tonalidades românticas que revestiram a abertura social do lirismo de Drummond". [il Essa marcha à ré consiste no abandono do estilo puro pelo estilo mesclado, isto é, deixa de lado o poema sem o vulgar e sem o sublime, para adotar a tensão entre o vulgar (prosaico ou grotesco) e o sério. Essa mudança de rumo persistiria em A Rosa do Povo.

Wagner Camilo analisa três poemas de Claro enigma, sob o título de "A Poética do Impasse" para destacar que nessa obra, passado o momento da comunicação com o mundo, do ideal social dos anos 40, o "eu" lírico se propõe uma "recusa inamistosa a toda e qualquer espécie de comunicação (e comunhão) com o leitor". [ii]

Marlene de Castro Correia, ao estudar o fazer poético de Drummond, revela que este se encontra ante o impasse de tentar "reduzir o irredutível", isto é, dar configuração verbal ao mundo. [iiil o próprio poeta afirma, em Rola mundo, que o mundo é "irredutível ao canto, superior à poesia". As idéias de ruptura ou impasse permeiam a obra de Carlos Drummond de Andrade, segundo seus estudiosos, quero, entretanto, apresentar mais um lance dessa discussão.

Parto da hipótese de que a tensão, em $A$ Rosa do Povo, não é apenas entre o sério e o vulgar, mas também em outros campos de realização poética, isto é: o temático, o formal, o metapoético, o ideológico. Cabe-me, pois, a busca dos aspectos que revelam tensão a fim de comprovar a amplitude sugerida.

A abertura do livro em questão se faz com dois metapoemas: Considerações 
do poema e Procura da poesia, que já trazem em si não apenas o embrião do impasse, mas o próprio impasse e o sentido da obra. A tensão específica em que se assentam esses poemas reside em o que a poesia representa (idéias, coisas, pessoas, emoções) e o que a poesia é (objeto verbal). O primeiro dos poemas, aliás, vive o conflito interno, pois o "eu" lírico abre seus versos destacando a liberdade das palavras que "não nascem amarradas" umas às outras, para logo em seguida dizer com orgulho que a sua polêmica pedra no meio do caminho se incorpora ao lado esquerdo, diz ainda "são meus" os vários poetas citados, também o "eu" lírico se apossa de "qualquer homem/ ao meio-dia em qualquer praça" "é tudo meu", declara-se "Poeta do finito e da matéria", pergunta-se: "Como fugir ao mínimo objeto/ ou recusar-se ao grande?" e conclui "Tal uma lâmina,/ o povo, meu poema, te atravessa".

A trajetória desse poema vai do questionamento sobre a sua construção como objeto de palavras, passa pela auto-referência, incorpora a relação intratextual, agrega o homem e a vida presente, não se furta ao grande nem ao pequeno e adquire clara dimensão social ao integrar linguagem e povo de modo original, como sugeria T.S. Eliot, ao propor que a verdadeira função social da poesia é manter viva a língua, renovandoa. [iv]

Procura da Poesia, ao contrário do primeiro texto, nega a poesia sobre acontecimentos ou incidentes pessoais, aconselha a não revelar os sentimentos nem cantar sua cidade e explicitamente nega a natureza e as relações: “O canto não é a natureza/ nem os homens em sociedade". Sugere ainda a não dramatizar, emocionarse, aborrecer-se e tampouco buscar na memória o tempo passado. Após esclarecer o que não é poesia, finalmente orienta o caminho, como se o fizesse a um jovem poeta incipiente: "Penetra surdamente no reino das palavras./ Lá estão os poemas que esperam ser escritos.". A partir daí, há toda uma valorização do mundo das palavras e seu potencial de poesia e elas interrogam quem entra em seu reino: "Trouxeste a chave?". Este poema, portanto, salienta a poesia como artefato verbal, criando até uma aparente contradição em relação aos temas até então desenvolvidos pelo poeta, exatamente o que o poema nega: memória, sua cidade, acontecimentos, sentimentos... Aparente porque aqui a negação está posta mais em função de negar a ingenuidade ante os assuntos que os assuntos em si. Ingenuidade não apenas em relação à concepção mesma de seus conteúdos, mas especialmente que esses conteúdos não realizam por si o poético, senão que este está na linguagem.

Os dois poemas ainda revelam outros impasses ou tensões que se ampliam no decorrer do livro. Em Considerações do poema, a contraposição e a convivência entre a reificação e a humanização nos tempos modernos se mostram nos versos: "O beijo ainda é um sinal, perdido embora,/ da ausência de comércio,/ boiando em tempos sujos."; a origem e o tempo passado em tensão com outro tempo e outro lugar aparecem em: "É minha terra/ e é ainda mais do que ela."; o poeta também não se nega ao grande ou ao pequeno, e seu canto "é tão baixo que sequer o escuta/ ouvido rente ao chão. Mas é tão alto/ que as pedras o absorvem". Procura da poesia, por seu turno, trabalha com a tensão da dicção do verso longo e do verso curto 
associados ao enjambement. Há versos com mais de vinte sílabas e outros com duas ou três, assim como, vários versos seguidos com mínima variação métrica. O poeta condensa num só poema as várias possibilidades de dicção do verso, produzindo às vezes efeitos poéticos interessantes como:

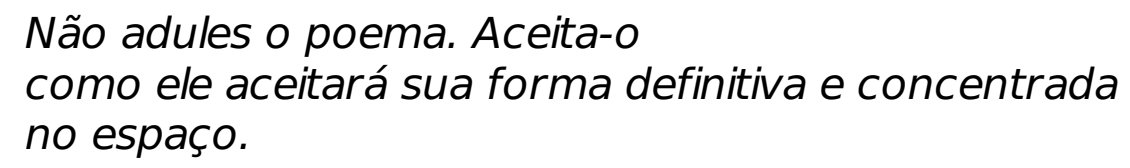

Não adules o poema. Aceita-o como ele aceitará sua forma definitiva e concentrada no espaço.

Chega mais perto e contempla as palavras.

Cada uma

tem mil faces sobre a face neutra

No primeiro conjunto de três versos, o segundo verso (longo) termina com a palavra "concentrada" e o verso seguinte se reduz a duas sílabas, mostrando a concentração espacial visualmente. Através do enjambement está sugerindo que o verso não deve se estender mais, já que é preciso se concentrar. Assim também no segundo conjunto de três versos: após convidar à contemplação das palavras num verso longo, reduz o segundo verso, propondo olhar mesmo cada palavra em particular, em seu mundo com suas múltiplas possibilidades.

O tom dos dois poemas permite ainda mais uma visada de tensão: enquanto Considerações do poema mostra um eu expansivo, que agrega e se expõe, uma primeira pessoa que se explicita "É tudo meu. Ser explosivo, sem fronteiras,/ por que falsa mesquinhez me rasgaria?"; Procura da poesia revela um eu contido que nega. Nega tanto que não se expõe, já que se dirige a um tu, orientando-o. É como se se escondesse no tu a quem admoesta.

Outro modo de tensão na obra está na dimensão espaço/tempo. Os mundos da infância, da família e da terra natal são constantes desde Alguma Poesia, mas a esse retorno ao passado e ao interior mineiro, agora se contrapõe o mundo urbano. Aquele um tempo rico para a poesia que se alimenta de memória, este um tempo pobre para a poesia, pois a desumanização é marcante na cidade. Voltar o olhar para o passado é deparar-se com poemas como: Nos áureos tempos, Ontem, Resíduo, Desfile, Retrato de família, Como um presente, No país dos Andrades. Encarar o agora significa conhecer A flor e a náusea, Anoitecer, Nosso tempo e todos os poemas que tratam da Segunda Guerra como: Carta a Stalingrado, Telegrama de Moscou, Mas viveremos, Com o russo em Berlim. Para melhor compreender a bipartição do mundo nessa construção poética, estudo A flor e a náusea para representar o tempo presente, e Retrato de família para caracterizar o passado.

Vejamos este último:

Este retrato de família está um tanto empoeirado. Já não se vê no rosto do pai 
quanto dinheiro ele ganhou.

Nas mãos dos tios não se percebem as viagens que ambos fizeram. $A$ avó ficou lisa, amarela, sem memórias da monarquia.

Os meninos, como estão mudados. $O$ rosto de Pedro é tranqüilo, usou os melhores sonhos.

E João não é mais mentiroso.

O jardim tornou-se fantástico. As flores são placas cinzentas. $E$ a areia, sob os pés extintos, é um oceano de névoa.

No semicírculo das cadeiras nota-se certo movimento. As crianças trocam de lugar, mas sem barulho: é um retrato.

Vinte anos é um grande tempo. Modela qualquer imagem.

Se uma figura vai murchando, outra, sorrindo, se propõe.

Esses estranhos assentados, meus parentes? Não acredito. São visitas se divertindo numa sala que se abre pouco.

Ficaram traços da família perdidos no jeito dos corpos. Bastante para sugerir que o corpo é cheio de surpresas.

A moldura deste retrato em vão prende suas personagens.

Estão ali voluntariamente, saberiam - se preciso - voar.

Poderiam sutilizar-se no claro-escuro do salão, ir morar no fundo dos móveis ou no bolso de velhos coletes.

A casa tem muitas gavetas e papéis, escadas compridas. Quem sabe a malícia das coisas, quando a matéria se aborrece?

$O$ retrato não me responde, 
ele me fita e se contempla

nos meus olhos empoeirados.

E no cristal se multiplicam

os parentes mortos e vivos.

Já não distingo os que se foram

dos que restaram. Percebo apenas

a estranha idéia de família

viajando através da carne.

Drummond já se nomeara, em Sentimento do mundo, o poeta do tempo presente, mas desde antes disso buscou na infância e nas lembranças assunto para seus versos. Parece, porém, que Itabira, ainda que presente, não voltará, pois "é apenas uma fotografia na parede". Portanto, são os olhos do presente tentando redescobrir o olhar de ontem. Daí que sempre serão dois olhares: o que consegue recuperar do ontem mesclado ao que agora volta ao passado. Ambos mostram tensão, pois há ao mesmo tempo a busca do passado (fuga do presente e memória) e a crítica a ele (crise em relação ao tempo da memória e consciência do presente - por isso dói).

O retrato agora observado é da família, não mais de Itabira. A poeira que o cobre também está nos olhos de quem observa: "Este retrato de familia/ está um tanto empoeirado."; "O retrato não me responde,/ ele me fita e se contempla/ nos meus olhos empoeirados". Portanto se é difícil ver bem as imagens do passado, isso se deve tanto às figuras esvaecidas quando aos olhos incapazes de ver com clareza, mercê do tempo e da distância. A idéia da diluição das lembranças na diluição das figuras é recorrente, a face de cada um hoje mostra coisa diferente do que a mente ainda traz: o rosto do pai não revela o seu dinheiro, as mãos dos tios não conduzem às suas viagens, a avó está apenas amarela, sua lembranças sumiram, os meninos mudaram e até o jardim "é um oceano de névoa". Após vinte anos, vem a dúvida de que sejam de fato parentes, mas "ficaram traços da família/ perdidos no jeito dos corpos". Não somente aos olhos do "eu" que lembra as imagens se enevoam, mas elas próprias "poderiam sutilizar-se" e se mesclar com os móveis ou as coisas do seu tempo, como se o "eu" que lembra as percebesse impregnadas nas coisas do passado. Retrato e "eu" se contemplam, como se um se visse no outro, assim, parentes vivos e mortos se confundem e se perde a noção de indivíduo para prevalecer a de família: "Percebo apenas/ a estranha idéia de família/ viajando através da carne".

Outros ingredientes contribuem na constituição do mundo do passado e sua relação com o presente. Entre eles, a incomunicabilidade. Não é mais possível ouvir a voz do pai perdida no tempo e até se quer negar, romper com a cadeia familiar: "A identidade do sangue age como cadeia,/ fora melhor rompê-la" ou "Quisera abrir um buraco, varar o túnel, largar minha terra,/ passando por baixo de seus problemas e lavouras, da eterna agência do correio,/ e inaugurar novos antepassados em uma nova cidade". Mas é impossível desfazer-se dessa família, além disso agora existe algum tipo 
de entendimento com o pai que no passado era impossível: "já não estás, e te sinto,/ não me falas, e te converso" ou "e tu que me dizes tanto/ disso que não me contas nada".

Há nisso tudo a irreversibilidade do tempo, mas uma vontade de fazer o que nunca foi feito em relação ao pai, homem rude, o faz revelar o desejo "de amá-lo sem qualquer disfarce, [...] corrigir o tempo,/ passar o calor/ de um lento carinho". Coisa tão impossível no presente quanto outrora: antes pela rudeza paterna, agora pela distância no tempo.

Cabe a pergunta: por que o poeta se arremessa ao passado com tanta insistência, em especial n'A rosa do povo? Talvez a resposta seja o tempo para o próprio poeta, que atinge a idade madura e anseia pela infância, como o faz em Desfile: com "o rosto no travesseiro,/ escuto o tempo fluindo [...] como vento no cabelo, fluindo: fiquei mais moço./ Já não tenho cicatriz". Ou como reconhece em Idade madura: "As lições da infância/ desaprendidas na idade madura", afinal, para que serviu a experiência se "Toda a água que possuía/ irrigava jardins particulares de atletas retirados, freiras surdas, funcionários demitidos", ficou, pois, a inutilidade do que tem e pode, daí o buscar o passado. Por isso que ele - o passado - está em tensão com o presente.

\section{Representando o presente, temos A flor e a náusea:}

Preso à minha classe e a algumas roupas, vou de branco pela rua cinzenta.

Melancolias, mercadorias espreitam-me.

Devo seguir até o enjôo?

Posso, sem armas, revoltar-me?

Olhos sujos no relógio da torre:

Não, o tempo não chegou de completa justiça.

O tempo é ainda de fezes, maus poemas, alucinações e espera.

O tempo pobre, o poeta pobre

fundem-se no mesmo impasse.

Em vão me tento explicar, os muros são surdos.

Sob a pele das palavras há cifras e códigos.

$O$ sol consola os doentes e não os renova.

As coisas. Que tristes são as coisas, consideradas sem ênfase.

Vomitar esse tédio sobre a cidade.

Quarenta anos e nenhum problema

resolvido, sequer colocado.

Nenhuma carta escrita nem recebida.

Todos os homens voltam para casa.

Estão menos livres mas levam jornais

e soletram o mundo, sabendo que o perdem.

Crimes da terra, como perdoa-los?

Tomei parte de muitos, outros escondi.

Alguns achei belos, foram publicados. 
Crimes suaves, que ajudam a viver.

Ração diária de erro, distribuída em casa.

Os ferozes padeiros do mal.

Os ferozes leiteiros do mal.

Pôr fogo em tudo, inclusive em mim.

Ao menino de 1918 chamavam anarquista.

Porém meu ódio é o melhor de mim.

Com ele me salvo

e dou a poucos uma esperança mínima.

Uma flor nasceu na rua!

Passem de longe, bondes, ônibus, rio de aço do tráfego.

Uma flor ainda desbotada

ilude a polícia, rompe o asfalto.

Façam completo silêncio, paralisem os negócios,

garanto que uma flor nasceu.

Sua cor não se percebe.

Suas pétalas não se abrem.

Seu nome não está nos livros.

É feia. Mas é realmente uma flor.

Sento-me no chão da capital do país às cinco horas da tarde e lentamente passo a mão nessa forma insegura.

Do lado das montanhas, nuvens maciças avolumam-se.

Pequenos pontos brancos movem-se no mar, galinhas em pânico.

É feia. Mas é uma flor. Furou o asfalto, o tédio, o nojo e o ódio.

No espaço urbano, o "eu" lírico se mescla com o ambiente, e o que é seu ou do local revelam-se semelhantes: "vou de branco pela rua cinzenta". No cinza está o branco que perdeu o vigor pela mistura do preto. Emoções misturam-se com coisas: "Melancolias, mercadorias espreitam-me". Há fusão de atitudes com comércio, isto é, o homem não vive em função do que é apenas, mas agregado às coisas e aos negócios, preso às circunstâncias de seu tempo. Os verbos, aliás, estão todos no presente do indicativo, confirmando a presentificação dos fatos. Estar neste tempo não é harmônico, daí as perguntas e o anseio de revolta. Mas esse tempo de fezes e maus poemas é o tempo em que o poeta se funde ao mundo, e desse mundo que parece vazio de poesia e infenso a ela, o poeta se apossa e faz a poesia sem luzes como o homem comum. Quem irá ouvi-la, se "os muros são surdos"? Quem irá entendê-la, se "sob a pele das palavras há cifras e códigos"? Disso decorre a insatisfação do poeta, cujos problemas permanecem sem solução, assim como os dos homens, que "estão menos livres mas levam jornais/ e soletram o mundo, sabendo que o perdem". Apesar de tudo, o poeta não se põe acima do mundo, pois considera que tomou parte de muitos crimes do mundo que chama de "Ração diária de erro".

Percebe-se o impasse em que vive o poeta: cantar o mundo em que está inserido, sabendo-o feio e percebendo-se feio nele, porque com ele está integrado. Assim, pois, seu canto que é uma espécie de salvação do homem no caos, também é 
mergulho nele e quase exaltação dele, já que é seu tema. Dessa forma essa poesia de “esperança mínima” estabelece seu sonho e seu limite nela mesma.

Mas “Uma flor nasceu na rua!”, isto é, há beleza neste caos, mas uma beleza pobre como o mundo pobre e o poeta pobre: "desbotada". Essa flor sem cor é uma flor, todavia, e se conseguiu romper o asfalto, é preciso que a vejam, para isso "paralisem os negócios". Não importa que é feia, o que conta é que é flor e faz o poeta sentar-se no "chão da capital do país às cinco horas da tarde" e passar "a mão nessa forma insegura". Num mundo sem sentido, qual o sentido da flor que vence "o asfalto, o tédio, o nojo e o ódio"? Sem dúvida, trata-se mais uma vez de um metapoema: a flor é metáfora do poema que nasce no mundo frio da cidade de homens vazios. A arte surge do desprezível, do feio e é uma possibilidade de beleza no sujo do mundo. Melhor dizendo, a arte poética é a construção do feio e do desprezível, mas não uma construção ingênua, por isso permite a reflexão sobre seu ato criativo e sobre o mundo criado em contigüidade com o mundo que interpreta.

A flor e a náusea e Nosso tempo representam um presente caótico, com um sistema capitalista sobre o qual "O poeta/ declina de toda a responsabilidade" e "promete ajudar/ a destruí-lo". Há outros poemas, porém, sobre o tempo presente, que revelam o maior caos - a guerra - e ainda assim, por contraditório que pareça, ali germina a esperança, pois se trata de eliminar um mal ainda maior que a própria guerra: o totalitarismo, a total falta de liberdade. $\mathrm{E}$ há, marcado pelo momento histórico, um apego do poeta a valores ideológicos socialistas. Veja-se Carta a

\section{Stalingrado:}

O mundo não acabou, pois que entre as ruínas

outros homens surgem, a face negra de pó e de pólvora,

e o hálito selvagem da liberdade

dilata os peitos, Stalingrado,

seus peitos que estalam e caem

enquanto outros, vingadores, se elevam.

Aí está a expressão da resistência, da esperança de liberdade. Dá "um enorme alento à alma desesperada/ e ao coração que duvida" saber que a resistência persiste. Embora tenha consciência das perdas dessa resistência, é o próprio ato de resistir que ilumina: "monte de escombros, entretanto resplandecente!". Há neste poema um luzir de esperança sobre a própria idéia de cidade, tão desumanizada em A flor e a náusea, pois Stalingrado é mais que a resistência armada contra um poder ditatorial, é a resistência de um tipo de vida sobre outro, é uma visão socialista sobre a capitalista. E o poeta humaniza a cidade: "sinto-te como uma criatura humana, e que és tu, Stalingrado, senão isto?" E mais adiante amplia a idéia de cidade para cidades: "As cidades podem vencer" e propõe: "as cidades, que se amarão e se defenderão contra tudo". Aqui já não se trata somente de luta armada, mas de todas as lutas desumanizadoras que ocorrem nas cidades, há aqui o que vem explícito no último verso: “a grande Cidade de amanhã erguerá a sua Ordem”. Existe, portanto, uma nova 
ordem a surgir, uma reconstrução e assim uma esperança.

Como no poema anteriormente analisado, há neste também uma disputa de espaço na cidade. Lá, pouco sobrou para a flor, ainda assim ela se mostrou viva e surgiu no caos; aqui, do caos nascerá outra flor, que pretende outra realidade, que propõe a superação do caos por uma nova ordem, sob a égide da esperança, pois Stalingrado, apesar de destruída, não foi derrotada. O que rege por conseguinte a poesia de Drummond é sempre a instabilidade, nunca há sossego ou acomodação.

Ao tratar da guerra, aparece a escolha pelas grandes temáticas poéticas, que nesta obra em especial adquirem destaque, como vimos. Por outro lado, a flor que rompe o asfalto representa a pequenez, o comum, o sem aura. Sobre o antônimo do grande, o mínimo, o sem luz, o quase mesquinho, o poema Vida menor é exemplo importante:

A fuga do real,

ainda mais longe a fuga do feérico,

mais longe de tudo, a fuga de si mesmo,

a fuga da fuga, o exílio

sem água e palavra, a perda

voluntária de amor e memória,

o eco

já não correspondendo ao apelo, e este fundindo-se,

a mão tornando-se enorme e desaparecendo

desfigurada, todos os gestos afinal impossíveis,

senão inúteis,

a desnecessidade do canto, e limpeza

da cor, nem braço a mover-se nem unha crescendo.

Não a morte, contudo.

Mas a vida: captada em sua forma irredutível,

já sem ornato ou comentário melódico,

vida a que aspiramos como paz no cansaço

(não a morte),

vida mínima, essencial; um início; um sono;

menos que terra, sem calor; sem ciência nem ironia;

o que se possa desejar de menos cruel: vida

em que o ar, não respirado, mas me envolva;

nenhum gasto de tecidos; ausência deles;

confusão entre manhã e tarde, já sem dor,

porque o tempo não mais se divide em seções; o tempo

elidido, domado.

Não o morto nem o eterno ou o divino,

apenas o vivo, o pequenino, calado, indiferente

e solitário vivo.

Isso eu procuro.

A opção pelo pequeno e pelo simples é parte da escolha do projeto modernista, que combate a poesia altissonante e grandiloqüente. Este poema começa por não escolher o real nem o mágico, ainda menos o si mesmo e renuncia o próprio amor e a memória, para escolher o eco que já distorceu o apelo. Apesar da negação de qualquer coisa, ainda que mínima, que simbolize ação ou fato, presença ou representação, o 
"eu" lírico não busca a morte, ao contrário, quer a vida "captada em sua forma irredutível", isto é, já sem as contingência a que está sujeita, nua em si mesma, inclusive liberta do tempo, seu algoz mais cruel. Ao querer a elisão do tempo, não opta pelo eterno, porque sua procura se restringe ao "solitário vivo".

Vida menor é um poema livre de quaisquer amarras tradicionais: sem divisão estrófica, com variação métrica e em versos brancos. Isso não significa mal feito, ao contrário, exige outros meios de envolvimento ou conquista do leitor. A variação métrica, por exemplo, é uma escolha produtiva. Nos oito primeiros versos, após iniciar por um verso curto, anunciando "A fuga do real", os seis próximos se avolumam para intensificar essa fuga, mas ao mesmo tempo a fuga se afunila, pois da fuga ao real chega-se à fuga de si e até da memória, para tornar-se apenas eco. Então, no sétimo verso, representando visualmente o esvaziamento da fuga, resta apenas "o eco" ocupando o verso inteiro; mas se lhe segue um longo verso, com sons nasais mesclados a oclusivos, como que criando sonoramente o eco, que já não corresponde ao apelo, pois nem apelo há. Nos versos 4,5,6 há o enjambement, sugerindo o alongamento da frase poética e intensificando a proposta de fuga.

Outro aspecto da elaboração poética da vida menor é a construção por oposições: há uma grande incidência de negações contrastando com afirmações. Começa com o título que afirma a vida ao mesmo tempo em que a limita. Assim também no início, a idéia de fuga é afirmativa, mas é fuga do real, portanto a negação do real para a poesia. Palavras como perda, sem, não, nem, menos que, prefixos como des, im, $i$, in contrastam com conjunções como mas, contudo ou palavras como essencial, vivo e isso revela o conflito que vive o "eu" lírico na sua procura pela vida menor. Se há mais palavras que contribuem para a negação ou o amiudamento, é porque o poeta faz esforço para construir claramente sua procura por algo "pequenino, calado, indiferente"; vida, entretanto, e liberta, original, "um início".

Ao entrelaçamento de contrários que permeia a obra drummondiana, acrescente-se a presença da escuridão em contraposição à aurora. Em Passagem da noite - título emblemático para a temática da obra que diz de tempos difíceis - o poeta afirma a presença da noite, não apenas a escuridão, mas uma noite maior, dentro de cada ser: “É noite. Sinto que é noite/ não porque a sombra descesse/[...] mas porque dentro de mim,/ no fundo de mim, o grito/ se calou, fez-se desânimo". Por outro lado, o contraponto da escuridão e do desalento é o dia: "Mas salve, olhar de alegria!/ E salve, dia que surge!". Esses pólos contrastantes e complementares aparecem no final de A morte do leiteiro, quando, após a morte do entregador de leite com um tiro de um morador assustado, amanhece poeticamente uma aurora fruto da mistura de leite e sangue. Também no poema Mas viveremos, imagina-se vislumbrar a aurora, mas apenas se trata de uma fogueira na noite. Oposições que se reúnem para dizer que a vida não é harmonia.

N'A rosa do povo, em que Drummond foi mais intensamente voltado para o mundo, ele centra, afinal, sua dicção no "eu" ou no outro? Em Considerações do poema, tudo gira em torno de como o "eu" se propõe a realizar o trabalho poético. Em 
Procura da poesia, o "eu" lírico se dirige a um outro. Mas o outro de fato aparece em poemas em que o mundo conquista o centro das atenções do poeta, mesmo que aí apareça uma primeira pessoa. Nosso tempo é um bom exemplo de poema centrado no tempo do poeta, nos homens, suas necessidades e frustrações, seus anseios e limites. Esse poema fala de "homens partidos", de um tempo em que "as leis não bastam" e o "eu" lírico procura a "precária síntese", a resposta que não encontra e então declara: "Calo-me, espero, decifro." e espera que as coisas melhorem, mas, não sendo coisa, revolta-se e precisa dizer desse tempo em que as coisas perderam o sentido. Há nesses versos a projeção do "eu" no todo. O poeta constata ainda que se trata de um tempo de isolamento, em que as pessoas estão divididas, em que os gestos perderam o sentido, pois são "avulsos". É ainda um tempo de "símbolos obscuros", de guerra, de escuridão que se estende, de lembranças, ainda que ácidas, mas é também tempo de silêncio, de "palavra indireta", pois o "espião janta conosco" e a política oprime já que está em tudo, é época de ditadura. A vida tornou-se mecânica, tudo tem hora marcada, os negócios envolvem as pessoas que se tornam massa humana e "servos do negócio". Há até o momento do lazer, que já não é mais prazer, mas obrigação. Propriedade, emprego, bancos, usuário, jornais são as palavras do momento, e as pessoas são menos gente, pois a tecnologia as substitui ou repara seus defeitos, os humanos se distanciam, já que as histórias se contam por correspondência e na mesa há "um copo, uma faca", na cama a solidão. O que importa são os bens: salvar a honra é salvar a herança. Vendem-se soluções para quaisquer problemas e até o pranto é produção teatral. Tudo é máscara, mas "o poeta/ declina de toda a responsabilidade/ na marcha do mundo capitalista" e "promete ajudar/ a destruílo". Não ficam dúvidas sobre a preocupação central desses versos: o mundo.

Desfile é poema centrado no "eu" e na consciência do tempo que passa e da idade madura que chegou. O outro aqui não tem espaço. Rosto encostado ao travesseiro, o "eu" volta ao tempo de menino e rememora sensações e fatos: o colégio, o cometa, a calça comprida, o conhecimento do dinheiro... Então, o mesmo fluir que o levou ao passado o traz ao presente com barba e mãos experientes. Perscruta o futuro e compreende que a morte levará consigo "um modo de ver" e se dá um tempo de vida ainda: "vinte anos ou pouco mais/ e tudo estará terminado". O mundo existe como um espaço do "eu", é ele que atravessa o tempo e as coisas que adquirem sentido ante sua face. Aí está o contraste com o poema anterior, em que o mundo era mostrado como uma realidade em que o "eu" estava inserido, o mundo funcionava com uma mecânica própria, que o "eu" negava ter ajudado a construir e se propunha a destruir. Em Idade madura, entretanto, ocorre outra relação do "eu" com o todo, há a sua diluição no todo quando os versos dizem: "serei, no circo, o palhaço,/ serei médico, faca de pão, remédio, toalha,/ serei bonde, barco, loja de calçados, igreja, enxovia,/ serei as coisas mais ordinárias e humanas, e também as excepcionais".

Merquior trata de a personificação do eu, Romano de Sant'Anna de diálogo a um, o que em Drummond é muito presente; o desdobramento do eu em um tu, como se dois em um, como se um e outro. Esse modo de portar-se poeticamente pode ser 
uma maneira de se pôr do outro lado do diálogo e de dar personalidade ao outro, assim vê e sente melhor o diálogo que não faz; ou esse comportamento revela a dificuldade de dialogar sobre principalmente o fazer poético ou sobre o mundo, pois é nesses poemas que mais intensamente aparece essa dicção, como é o caso de Considerações do poema: "os temas passam,/ eu sei que passarão, mas tu resistes,/ e cresces como fogo". Ou como faz em Procura da poesia, quando se dirige a um tu que pode ser ele mesmo: "Não faças versos de acontecimentos". Em Resíduo, diz ainda o poeta: "Fica um pouco de teu queixo/ no queixo te tua filha./ De teu áspero silêncio / um pouco ficou, um pouco". Isso é autobiográfico. Está aí outra nuance, outra variável nesse poeta que não encontra apaziguamento.

A temática amorosa, rara neste livro, adquire também caráter dinâmico: é prazer e dor. Dois poemas freqüentam o tema: 0 mito e Caso do vestido. $O$ primeiro trabalha com a imagem da mulher inacessível, que nem nome tem (Fulana). É mulher desejável, desfrutável, que o poeta quer possuir, imagina-a nua, chega duvidar de sua existência, procura-a e não a encontra, sonha com suas ações e não sabe definir quais sejam, se propõe, de qualquer modo, chamar a sua atenção, imaginandose até morto diante de seu edifício, mas sabe que "Fulana quer homens fortes" e ele se considera enfermo. Até que o "poeta precário" reconhece "que fez de Fulana um mito" e decide "construir outra Fulana" a quem chama de "Amiga" e diz que "afinal nos compreendemos", pois nem ela brilha nem ele sofre e descobre que são "uma coisa tão diversa/ da que pensava que fôssemos.

Nesse poema o desencontro amoroso se dá pela idealização da mulher e assim se cria o afastamento, já que ela se torna inatingível. Mito é utopia, algo avesso ao pensamento lógico, personagem exagerado pela imaginação. Fulana é tudo isso, e é também um produto da moderna ciência e dos cosméticos publicitários, por isso frustra, é dor e deprime. Quando o poeta constrói outra sem o sorriso burguês, sem o sentido de produto ou objeto, aí eles se identificam e ao próprio mundo, onde cabe outra realidade "sem classe e impostos", a que o poeta chama de "fase gloriosa,/ de contradições extintas", o que não deixa de ser também uma utopia, mas então há o apaziguamento.

Em o Caso do vestido, as filhas pressionam a mãe a contar um fato que ela quer esconder, mas acaba contando: o marido se envolvera com outra mulher, uma prostituta e com ela se foi. A mãe sofreu muito nessa ausência do marido. Um dia, a prostituta voltou sozinha para pedir perdão à mulher, pois compreendeu o que é querer um homem e ser desprezada por ele, já que o marido que roubara não mais a queria. Assim, como pedido de perdão, deixou o vestido "última peça de luxo/ que guardei como lembrança/ daquele dia de cobra,/ da maior humilhação", e se foi, na mesma hora em que na curva do caminho apontava o marido retornando. A volta dele fez tudo parecer um sonho, e o vestido pendurado num prego é como se não existisse. A fala da mãe é interrompida pelo barulho do pai subindo a escada.

O amor fundado na sexualidade é mostrado como paixão passageira, assim que o objeto do desejo muda, o interesse muda também: “confessou que só gostava/ 
de mim como era dantes". Também mostra os diferentes papéis do homem e da mulher na relação amorosa: ele, ativo, sempre buscando o novo, tendo amantes; ela na espera, aceitando, sofrendo em silêncio. Entretanto, mesmo com toda a dor que a ausência do marido causou, fazendo-a sustentar sozinha as filhas, tendo que se desfazer das jóias, machucando as mãos, ainda assim, quando ele volta, ela o recebe sem dizer palavra e se sente acalentada, reencontrando a paz. Seria porque venceu a disputa com a outra? O certo é que o vestido permanece no prego como um símbolo de vitória e dor, uma lembrança que a obriga a percorrer os caminhos da memória e recuperar aí sua perda e sua conquista. O que significará para o marido aquele vestido que ele mal olhou quando retornou? Isso já é outro ponto de vista, ou apenas especulação.

Caso do vestido é um poema que se pode categorizar como dramático, assim como Morte do leiteiro. Note-se que os tons dos textos de Drummond nessa obra formam também uma complementação por oposição, de um lado está o tom épico dos textos sobre a guerra, aproximados do dramático citado; do outro lado existe o tom prosaico de $\mathbf{A}$ flor e a náusea ou de $\mathbf{O}$ elefante, e há ainda poemas em que os tons se mesclam como em Nosso tempo, em que o épico do caos se casa com o caos do cotidiano, criando a situação dramática de uma época.

No caminho de buscar as antíteses drummondianas, destacam-se algumas associações raras que quebram a lógica da linguagem. Nesse sentido, a aproximação inusitada entre palavras que designam algo concreto com as que caracterizam algo abstrato é um dos achados do poeta, como faz em O elefante: "e o encho de algodão, de paina, de doçura" [...] "seu conteúdo de perdão, de carícia, de pluma, de algodão". É verdade que o que se aproxima são coisas suaves, mas encher um elefante de brinquedo de doçura é mais Ihe atribuir competência humana, enquanto algodão e paina de fato preenchem seu boneco vazio. Essa aproximação é produtiva na medida que se dá à figura criada algo que lhe vai dentro, quer seja físico ou não, até porque se pode ter no elefante uma metáfora do poeta, daí seu conteúdo ser material e imaterial. Em A morte do leiteiro aparecem os versos "No ladrilho já sereno" e depois "objetos confusos", ambos expressões que outra vez tocam o sensível com o objeto material, dando vida à descrição do ambiente em que a tragédia acontece, como se as próprias coisas ficassem impregnadas das sensações de quem deu o tiro e de quem o recebeu e caiu morto. Em outros poemas, variadas expressões representam o referido casamento de opostos, veja-se, por exemplo "canoa sem fado e peixe", "manter esse gelo digno", "pinga esta gota absurda", "Este vidro de relógio partido em mil esperanças", "Melancolias, mercadorias espreitam-me", "A neblina gelou-me até os nervos e as tias".

Se iniciamos o levantamento salientando a metapoesia que impregna totalmente os dois primeiros poemas, queremos agora mostrar que no início ela veio concentrada, densa e direcionando uma proposta de leitura da obra por oposições, mas que no decorrer do livro, o poeta semeia versos metapoéticos, realimentando sua proposição primeira. Assim, há concentração e dispersão dos versos que apresentam o fazer 
poético.

Logo em A flor e a náusea Drummond planta sua primeira semente híbrida, revelando o que podia parecer oposição numa complementação: "O tempo pobre, o poeta pobre/ fundem-se no mesmo impasse./ Em vão me tento explicar, os muros são surdos". Percebe-se que o poeta não vive alheio a seu tempo, são uma só coisa, uma resposta somente. O tempo impregna o poeta que mancha sua poesia, como a nódoa no terno branco tão bem apanhada por Manuel Bandeira. [V] Outra semeadura acontece em Nosso tempo: "tenho palavras em mim buscando canal,/ são roucas e duras,/ irritadas, enérgicas,/ comprimidas há tanto tempo,/ perderam o sentido, apenas querem explodir". Aí está a consciência de que é com a palavra que se fará a explosão daquilo que está preso, mesmo que as palavras tenham perdido a sua motivação primeira. Se elas ainda querem explodir é porque estão motivadas pela necessidade do poeta e não mais apenas pelo impulso do homem revoltado. Em Ontem, fica bem explícito o papel do poeta como aquele que, ao escrever, espalha o que vê em si: "Eis está gravado/ não no ar, em mim,/ que por minha vez/ escrevo, dissipo". Em Fragilidade, a madureza do poeta sabe o limite da palavra, a incapacidade do verbo de captar a vida, até porque poesia é uma construção, não imitação da realidade: "Este verso, apenas um arabesco/ em torno do elemento essencial - inatingível". Ou de outra sorte: "Ninguém me fará calar, gritarei sempre/ que se abafe um prazer, apontarei os desanimados", afirma o poeta em Idade madura, revelando a postura comprometida. Já em América, surge a incapacidade de relatar: "a mão escreveu tanto, e não sabe contar!", para em Cidade prevista, negar a própria escrita: "O que escrevi não conta./ O que desejei é tudo". Mas em Mário de Andrade desce aos infernos, põe todo o impulso da necessidade premente de dizer, pois o tempo não melhorará o canto nem mudará a situação, é preciso dizer agora, pois agora é que pulsa: “É preciso tirar da boca urgente/ o canto rápido, ziguezagueante, rouco,/ feito da impureza do minuto".

Eis os impasses de um poeta que chega à idade madura consciente de seu papel e de seu limite, mas um poeta que vive a urgência de dizer, pois afirma que descobriu "na pele certos sinais que aos vinte anos não via". Esses sinais da maturidade the permitem andar "cada vez menos solitário", "embora também se acovardem" (Idade madura). Drummond nunca foi um poeta sossegado, dos que aceitam as contingências, mas em face da madureza e do momento histórico que viveu nos anos quarenta do século vinte, o passado tomou dimensão especial, tornou-se mais intenso, quase como se fosse uma fuga de um tempo cruel. Por outro lado, também mergulhou no presente quase comvolúpia e nele construiu páginas memoráveis da poesia brasileira.

Não há sossego na poesia de Carlos Drummond de Andrade: quer no passado evocado pela memória, quer no presente fruto da observação, o "eu" lírico se depara com as angústias próprias da vida, o que configura sua poesia como em constante dialética, continuamente alimentando um impasse que não se resolve, até porque é o próprio sentido da existência humana: enigma. 


\section{Bibliografia}

ANDRADE, Carlos Drummond de. Alguma Poesia. 3 ed. Rio de Janeiro: Record, 2002. Claro enigma. 15 ed. Rio de Janeiro: Record 2002. Rosa do povo. 2 ed. Rio de Janeiro: Record, s/d. Sentimento do mundo. 3 ed. Rio de Janeiro: Record, 2002.

AZEVEDO, Carlito Et all. Inimigo Rumor $n^{0}$ 13. Lisboa - Portugal, Rio de Janeiro - Brasil: Editora Vozes, 2002.

BANDEIRA, Manuel. Antologia poética. São Paulo: Círculo do livro S.A., 1978.

CAMILO, Wagner. Drummond: Da Rosa do Povo à Rosa das Trevas. São Paulo: Eteliê Editorial, 2001.

CORREIA, Marlene de Castro. Drummond: a magia lúcida. Rio de Janeiro: Jorge Zahar Ed., 2002.

ELIOT, T.S. A essência da poesia. Rio de Janeiro: Arte-Nova, 1972.

MARIA, Lúcia de. Drummond: um olhar amoroso. São Paulo: Escrituras Editora, 2002.

MERQUIOR, José Guilherme. Verso universo em Drummond. Trad. Marly de Oliveira. Rio de Janeiro: José Olímpio, Secretaria de Estado de Cultura, Ciência e Tecnologia, 1975.

[i] MERQUIOR, J. G. Verso universo em Drummond. Rio de Janeiro: J. Olympio, Secretaria de Estado de Cultura, Ciência e Tecnologia, 1975, p. 55.

[iil CAMILO, W. Drummond: da rosa do povo à rosa das trevas. São Paulo: Ateliê Editorial, 2001, p.203.

[iii] CORREIA, M.de C. Drummond: a magia lúcida. Rio de Janeiro: Jorge Zahar Ed., 2002, p. 134.

[iv]A Função Social da Poesia: conferência apresentada em Paris, em 1945.

[v] Refiro-me ao poema Nova poética, do livro Belo belo, de Manuel Bandeira. 